\title{
A Idade Média entre o "poder público" e a "centralização política" itinerários de uma construção historiográfica*
}

\section{The Middle Ages between "public sphere" and "political centralization"} itineraries for a historiographical construction ${ }^{* *}$

\author{
NÉRI DE BARROS ALMEIDA \\ Livre Docente \\ Departamento de História/Unicamp \\ Distr. Barão Geraldo \\ 13083-970 - Campinas, SP - Brasil \\ Caixa-Postal: 6110 \\ neridebarros@gmail.com
}

RESUMO A violência é um paradigma de primeira importância para o estabelecimento de interpretações gerais da Idade Média. Este texto pretende colocar sua validade em questão através de dois procedimentos. Em primeiro lugar, discutindo sua ligação com o papel que a Idade Média desempenha na historiografia contemporânea, de contraponto às formas sociais e políticas modernas (notadamente o Estado centralizado e seu monopólio da violência). Em segundo lugar, procurando definir o ponto de

* Artigo recebido em: 07/05/2010. Autor convidado.

** Este texto transcreve aula apresentada em concurso de Livre Docência em dezembro de 2009, no qual defendi o trabalho intitulado História e historiadores da Idade Média. Agradeço as considerações apresentadas na ocasião pela banca constituída pelos professores e colegas Vânia Leite Fróes, Maria Eurydice de Barros Ribeiro, José Rivair Macedo, Paulo Miceli e Pedro Paulo Funari, que a presidiu. 
vista dos próprios historiadores medievais a respeito das violências que registram.

Palavras-chave Historiografia, violência, História

ABSTRACT Violence is a paradigm of first importance for the establishment of general interpretations of the Middle Ages. This text pretends to bring its validity into question by two procedures. In first discussing its connection with the role that the Middle Ages plays in contemporaneous historiography, in counterpoint to modern political and social forms (specially the centralized state and its monopoly of violence). Second place trying to define the point of view of the medieval historians about the violence that they record.

Keywords Historiography, violence, History

Bernard Guenée abre sua grande obra, Histore et culture historique dans l'Occident médiévale, ${ }^{1}$ afirmando que "a Idade Média nasceu do desprezo". Guenée tinha diante de si um desses problemas que põem em evidência idéias preconcebidas e preconceituosas a respeito da Idade Média. Tratavase de verificar se os autores medievais envolvidos com projetos de escrita de "histórias" teriam de fato produzido algo que pudesse merecer este nome e assim, se eles mesmos poderiam receber a honrosa qualificação de "historiadores". O problema abordado por Guenée era tão elementar afinal saber se havia historiadores na Idade Média pode não mudar muito a idéia que se tem do período - quanto pertinente - pois capaz de (uma vez que a resposta encontrada fosse afirmativa) mudar a idéia que fazemos do alcance de nossa capacidade investigativa. Afinal, estamos sempre investidos da melhor perspectiva e das ferramentas conceituais mais precisas? O desprezo pela Idade Média é parente próximo da satisfação que temos diante das fórmulas simplificadoras que dão conta do período, das quais "Idade das Trevas" é apenas a mais evidente. Estas se sustentam em parte na certeza de que aquilo que é pertinente ao conhecimento deste período, nele se encerra, tendo pouca ou nenhuma influência nas zonas de saber cronologicamente vizinhas.

O desprezo pela Idade Média é antigo, mas sujeito tanto a nuances quanto à evolução. O epíteto "Idade das Trevas" é poderoso. Não se trata de uma adjetivação simples, mas de uma verdadeira idéia-tese capaz de explicar mil anos da história ocidental. Dessa forma, não surpreende que a

1 GUENÉE, Bernard. Histoire et culture historique dans l'Occident médiéval. Paris: Aubier, 1991. 
popularização do conhecimento da Idade Média seja tão pouco exigente. Na verdade, basta que se confirme ao infinito aquilo que já se sabe: a Idade Média foi um período da história do Ocidente caracterizado pelo controle da aristocracia sobre o campesinato, por meio da força das armas e com o apoio do clero que, manipulando medos de fundamentação religiosa, garantiam o controle ideológico e a submissão da sociedade. Essa síntese sumária de todo um período histórico, absolutamente improvável de ser aplicada pelos historiadores a qualquer outra época, é reconhecida, sem remorsos, como válida e suficiente para a Idade Média. A auto-suficiência dessa definição estrita oculta toda uma época sob algumas poucas palavras pretensamente "esclarecedoras" e "verdadeiras". Podemos dizer mesmo que neste ocultamento está encerrada a função histórica do período. Desde que respeitados os limites bem estabelecidos de suas "Trevas", a Idade Média pode prestar-se a todos os conteúdos.

No entanto, o desprezo pelo período não se manifesta apenas nas fronteiras tenebrosas que lhe foram impostas, mas também nas luzes que por vezes se procurou lançar em seu interior. É dessa forma que atuam, por exemplo, os esforços de "reabilitação" da Idade Média que pretendem explorar seu "exotismo". Desse ponto de vista, o valor da Idade Média passa a residir em sua capacidade de nos revelar suas entranhas mágicas e maravilhosas que acolhem e dão vida a formas e experiências sociais desconhecidas, ou esquecidas, exercendo uma função mais ou menos parecida com aquela que, entre os anos 1940 a 1970, tiveram as "fantasias" e "expectativas" em torno dos Ovnis e da vida extraterrestre. Dessas luzes saíram muitas histórias que os documentos não contam e lá entraram muito das nossas fantasias evasivas. Afinal, resguardados os princípios da crítica documental - que de resto definem desde o século XIX a especificidade do conhecimento histórico - o que pode ser dito sobre a maneira como os "camponeses" ${ }^{2}$ viviam a vida religiosa, a sexualidade e as investidas do poder, se temos uma documentação socialmente limitadíssima, culturalmente orientada por topoi bem estabelecidos e rigorosamente tributária de "autoridades" passadas? Diante disso tornou-se comum aplicar fórmulas explicativas que atribuíam caráter pagão, logo anticristão ou, na melhor das hipóteses, "para-cristão", a um sem número de dados esparsos ou de eventos. Afinal, os banquetes noturnos sobre as tumbas dos mortos cuja recriminação cruza a Idade Média pelas mãos dos homens da Igreja aconteciam, ou não? A repetição das censuras eclesiásticas indica a persistência das práticas descritas nos documentos ou a força de um modelo explicativo

2 Eis aqui já um de nossos abusos conceituais e/ou teóricos, uma vez que a figura do produtor, que o termo camponês encerra não dá conta do homem que na Idade Média vive com sua família em uma tenência submetida ou não a um senhor (que pode ser leigo ou eclesiásticos), localizada ou não próxima a uma cidade, à qual suas terras podem ou não estar de alguma forma vinculadas (do ponto de vista jurídico, religioso ou econômico). 
adotado pelos escritores medievais às autoridades do passado que estabeleceram padrões de relacionamento da lgreja com sua assistência? A chegada dos normandos pagãos representou uma invasão de paganismo ou fomentou sua revivescência sob o "verniz" da cristianização? Será que a rapidez com que os normandos se adaptaram aos modelos políticos e, como diria Dominique Barthélemy, aos "costumes cavaleirescos" em vigor nas regiões em que se estabeleceram não evidenciam a rapidez de sua conversão e, mais do que isso, seu claro e objetivo interesse por ela? 0 pragmatismo dessa decisão por si mesmo liberaria da necessidade de corresponder de forma plena ao compromisso assumido? Recuando um pouco mais, a elite senatorial que a partir do século VI povoa o episcopado cristão é menos comprometida com o cristianismo devido ao pragmatismo de sua adesão a ele? Parece-me que se trata exatamente do contrário. 0 pragmatismo força a seriedade do compromisso.

Essa Idade Média oferece o exotismo e, por vezes, o heroísmo que nossas fantasias demandam. A paz de Deus, as cruzadas e as heresias, foram movimentos sociais? Revelaram a "alma do povo" oculta pela mão pesada dos poderosos? Como defender essa idéia? Que documentos permitem fazê-lo? Novamente, onde parecia haver esclarecimento, nos deparamos com muros espessos que se interpõem entre nós e a Idade Média. Do outro lado desses muros, permanecem guardadas nas linhas singelas de documentos - incontornavelmente limitados - o que a Idade Média ainda pode vir a ser.

Essa dileta Idade Média das Luzes se comporta - dizemos "se comporta", pois ela tem a mesma aparência viva dos nossos sistemas virtuais - como se um período histórico inteiro coubesse num quadro de Bruegel, em especial aqueles dedicados ao universo atraente e perturbador dos jogos infantis. Aqui observamos o mesmo fenômeno que marca a concepção de "Idade das Trevas": todos os conteúdos represados por limites invulneráveis. Observamos assim que, seja pelo lado da detração ou do elogio, a Idade Média é sempre alvo de desprezo. Nos dois casos mencionados, que podem parecer tão distintos, a Idade Média ocupa a mesma função na cultura história: ${ }^{3}$ servir de campo de provas, de recurso para a construção controversa de identidades de outros períodos históricos, e dessa forma interessa que seja mantida no ocultamento, ou seja, considerada oculta. 0 "ocultamento", portanto, une as duas pontas da tradição recente de nossas opiniões a respeito da ldade Média.

Essa "cidadela" da história medieval pode ser facilmente reconhecível no plano da imaginação histórica - tanto aquela que conforma a memória

3 Refiro-me mais uma vez aqui à obra de Guenné. Nela, este autor entende a "cultura histórica" como o conjunto da produção do conhecimento histórico (do historiador à sua biblioteca) e sua transposição para a sociedade onde atua na formação de uma memória histórica. 
histórica comum quanto a que estabelece a própria produção do conhecimento histórico pelos historiadores profissionais - se pensarmos que se trata de um período marcado por rupturas. O lugar que o recurso analítico da "ruptura" ocupa na definição da Idade Média é de tal importância que questioná-lo implica em colocar em suspenso a validade de grande número de teses que estabelecem amplamente o campo do conhecimento histórico a seu respeito. Neste caso, a imagem do período vacila, tanto no senso comum, quanto nas academias. Tais rupturas se verificam fundamentalmente no campo político. Pode-se pensar que isso simplesmente decorre do fato de que a idéia que temos de Idade Média é em boa medida resultado das elaborações do século XIX, contexto em que a história política foi hegemônica. No entanto, a despeito de todas as "novidades" das décadas que separam o último terço do século XIX de nós, esses limites não viram sua natureza política mudada de forma substancial.

De um extremo a outro de nossa concepção de Idade Média imperam rupturas políticas. Podemos afirmar que nenhum outro período foi construído em tão estreita dependência deste conceito. Ruptura inicial com o Império por obra da "pulverização" e "barbarização" política que impera a partir do século V; ruptura final entre "monarquias incipientes e hesitantes", "feudais" e o Estado Moderno. Mas também ruptura - política interna - consagrada pela "efêmera restauração imperial intentada pelos carolíngios" situada entre a "anarquia bárbara" dos primeiros séculos medievais e a "anarquia feudal" que a sucedeu. Não é preciso insistir que este esquema geral marca a cultura e a memória histórica contemporâneas. Ele ajuda a exibir o quanto o desprezo recente pela Idade Média foi produzido como um artifício em favor da idéia de superioridade das formas políticas modernas - entenda-se o Estado e sua estrutura institucional - e sua auto-proclamada capacidade de centralização e ordenamento, em que um dos elementos postos em destaque é a resultante pacificação da sociedade através do monopólio eficaz da violência.

Não podemos deixar de notar que o desprezo pela Idade Média tem diversas e remotas origens. O próprio Guenée evoca na abertura de seu livro o quanto ele se deve a artistas e literatos dos séculos XIV e XV, a políticos e religiosos protestantes dos séculos XVI e XVII e a revolucionários do século XVIII. No entanto, a cultura histórica atual amadureceu nos últimos cento e cinqüenta anos à sombra do ideal político moderno. A Idade Média se estabelece como disciplina da história durante seu triunfo tornando-se então seu duplo inverso e oculto. A idéia de Idade Média se conforma no ambiente histórico em que se dá o auge da apologia da modernidade e do Estado Moderno. Este período evidencia as excelências dessa formação política que triunfa em oposição a ele mesmo. Dois exemplos dessa situação geral: em primeiro lugar, a ruptura entre Antiguidade e Idade Média, tradicionalmente situada no plano do desaparecimento das instituições 
públicas. A presença maciça dos bárbaros no território do Império teria acarretado um rebaixamento civilizacional, expresso no desaparecimento das formas políticas centralizadas e na pulverização do poder, que passaria a ser exercido exclusivamente segundo a vontade de seus plenipotenciários apoiados na força das armas. Resultando disso, teríamos uma sociedade à beira de dissolver-se sob os golpes da violência guerreira, instrumento da luta encarniçada pelo poder. Em segundo lugar, temos um exemplo extraído da Idade Média edulcorada dos românticos. Alguns, como Michelet, ${ }^{4}$ viram na Idade Média o berço do povo e da nação. A positividade dessa visão supostamente que superaria a ruptura entre Idade Média e modernidade pode, no entanto, facilmente ser posta a prova se pensarmos um pouco mais de que "povo" e de que "nação" se tratava. Esse "povo", contribuição medieval à modernidade, seria portador de dados de caráter coletivo, que propiciaria o desenvolvimento do espírito nacional de que são feitas as nações. No entanto, a Idade Média realizaria apenas o represamento de uma realidade potencial que apenas a modernidade política levaria à sua plenitude. A monarquia tardo-medieval desse ponto de vista teria sido fundamentalmente o espaço que permitiria a expressão a arbitragem das diferenças internas ao conjunto "povo". Nesse sentido, a monarquia medieval pode apenas ser entendida como um sistema político de passagem, cuja superação se dá em favor do povo e das formas políticas que lhe são afeitas. A monarquia arbitra as diferenças minimizando seus efeitos, mas não resolve definitivamente os problemas políticos do sistema aristocrático. São evidentes nos dois exemplos o rigor dos limites concebidos entre Idade Média e modernidade, bem como a importância para seu estabelecimento das idéias de centralização e descentralização política articuladas às idéias de governo efetivo (ou sua ausência). Mais recentemente, a história das mentalidades e a antropologia histórica tradicional, pouco fizeram para colocar a Idade Média fora do estereótipo de época anárquica e violenta. Mudando os problemas ou o ponto de vista para sua observação, ambas mantiveram o paradigma da violência. ${ }^{5}$

Não pretendemos negar que a Idade Média tenha sido uma época violenta. Nosso propósito também não é sugerir novos termos para a qualificação dessa violência, atenuando-a e mostrando seus pontos realmente cruentos. ${ }^{6}$ Pretendemos colocar o estereótipo em evidência e tratar um de seus aspectos mais importantes: o fato que essa chave interpretativa po-

4 MICHELET, Jules. Histoire de France. Paris: Ed. A. Lacroix, 1880, t.VI.

5 Nota-se isso tanto em estudos que se detém ao "teor violento da vida" - segundo expressão cunhada por Huizinga - passando por aqueles que buscam descrever seus fundamentos místicos (a insegurança num mundo submetido pelo conflito entre forças sobrenaturais e pela lógica de pecados e castigos) ou os estudos da violência civil que valorizam seu aspecto faidal e, portanto familiar, negando sua inserção na lógica do poder público.

6 Dominique Barthélemy apresentou recentemente uma síntese importante de suas considerações a este respeito. BARTHELEMY, Dominique. A cavalaria. Da Germânia antiga à França do século XII. Campinas: Editora da Unicamp, 2010 . 
derosa, que condiciona boa parte das leituras ulteriores, foi estabelecida a partir de pressupostos externos ao período. A Idade Média é vista pelo prisma da violência, da guerra generalizada e da anarquia, em primeiro lugar, porque esta é uma forma simples de explicá-la, pois descreve uma situação que é o inverso da experiência do observador moderno. Fazendo isso, ela justifica as formas políticas modernas. Portanto, as idéias de inexistência de Estado e de instituições públicas e de violência generalizada formam um núcleo explicativo ideologicamente muito importante. Nele, a violência ocupa uma posição ordenadora e explicativa maior uma vez que ela seria o argumento decisivo para a constatação da privatização do poder e do desaparecimento das instituições públicas. O elogio do Estado moderno centralizador estabeleceu uma chave de leitura histórica poderosa que associou de forma indelével, por um lado, poder público e centralização política e, por outro, descentralização e poder privatizado. À Idade Média cabe a função de comprovar este modelo político e, ao mesmo tempo, de fazer o elogio da superioridade da forma moderna, centralizadora em termos jurídicos, administrativos e militares. Excetuando a fugaz iniciativa carolíngia - muitas vezes encarada mais como um exemplo da "incapacidade" para uma experiência de poder público do período do que como exceção ao estado anárquico - não se verificaria aí a existência de iniciativas de poder de caráter público. Tudo isso que faz com que a violência seja um caminho importante através do qual podemos fazer a crítica das idéias hegemônicas a respeito da ldade Média e, ao mesmo tempo, a crítica de nossa crítica dos documentos do período. Afinal, o que pode ser afirmado a partir deles?

Três questões decorrem das considerações apresentadas na primeira parte deste texto. A reflexão a seu respeito orientará a condução da sua segunda parte. Em primeiro lugar: o que efetivamente os registros históricos permitem afirmar sobre a violência e seu estatuto na Idade Média? Em segundo lugar: quanto o caráter eclesiástico da maior parte dos documentos legados pelo período pode ter marcado a forma, a freqüência e a intensidade dos registros da violência guerreira? Por fim, se podemos estar enganados a respeito do colapso das formas políticas públicas durante a Idade Média, o que os documentos permitem afirmar sobre formas eficazes de governo em vigor, sobretudo em suas fases supostamente mais "anárquicas"?

Entre 1946 e 1947 Georges Duby, que se dizia de maneira justa e honesta, um "historiador da sociedade feudal", publicou o estudo Recherches sur l'évolution des institutions judiciaires pendant le $X$ e. et Xle siècle dans le sud de la Bourgogne. ${ }^{7}$ Este artigo, embora dissesse respeito a região e época precisos - baseado em documentação cluniacense referente ao Mâconnais do início da época feudal - teve grande posteridade na confecção de

7 DUBY, G. Recherches sur l'évolution des institutions judiciaires pendent le $X^{e}$ et le $\mathrm{Xl}^{\mathrm{e}}$ siècles dans le sud de la Bourgogne. Le Moyen Age, v.52, p.149-194 e v.53, p.15-38, 1946-1947. 
modelos de ordem mais geral, sobretudo aqueles comprometidos com a tese de que teria ocorrido nos arredores do ano mil uma "mutação feudal" 8 caracterizada pela ruptura política e social com o período precedente. Segundo Duby a desintegração da unidade política carolíngia no século IX teria dado origem em um primeiro momento a grandes principados territoriais. O movimento de desintegração não para aí, continuando até o nível das castelanias que, ao redor do ano mil, se emancipam da autoridade condal. Tais castelanias se tornam células de primeira importância da sociedade mudando seus fundamentos. Os castelões usurpam as prerrogativas do poder público e fazem pesar sobre o campesinato ao redor - alodial ou não - um a dominação fundamentada no poder de suas muralhas e das armas de seus guerreiros, os milites. Dessa forma o senhorio banal se uniria ao senhorio fundiário e se torna preponderante subjugando os homens a seu poder. As instituições judiciárias antigas se desfazem em proveito da justiça senhorial. Dessa forma os "costumes senhoriais" se instalam e tomam força de lei. A condição de livres e não livres se aproxima se confundindo em uma forma nova de dependência, uma nova servidão. Na castelania a distinção que se impõe é aquela entre os que estão submetidos aos costumes e às "exações" senhoriais e os que estão isentos delas porque contribuem para sua cobrança. A sociedade passa a estar distinguida a partir de então entre inermes e milites. Aparece dessa forma uma classe social nova, a cavalaria, que aspira à nobreza e acaba por se agregar a ela.

Entre aqueles que não se tornaram entusiastas da "mutação feudal", a crítica ao modelo acima descrito avançou em alguns sentidos fundamentais. Estes historiadores minimizam o declínio da autoridade condal e da "privatização do poder" e questionam a ascensão das castelanias independentes. Para eles nunca teve lugar uma "anarquia feudal" e aquilo que era encarado como generalização dos conflitos armados passou a ser visto em seu caráter pontual, como embates que aparecem quando a autoridade condal não consegue impor sua autoridade aos castelões. Dessa forma eles evidenciam a permanência da autoridade condal. E a idéia de uma crise única que culmina no ano mil desaparece em função de crises reais em diferentes momentos resultantes muitas vezes de conflitos dinásticos e, portanto, de arranjos políticos. Estes conflitos não são devedores da ascensão de uma nova classe vinda das franjas da aristocracia guerreira que usurpa o poderio público dos grandes, notadamente reis e condes.

A multiplicação de castelos nas proximidades do ano mil mostra que a luta pelo poder passava então pela posse de fortalezas e o controle dos

8 Duby não pode ser a rigor considerado um mutacionista. No que diz respeito a esta corrente de interpretações têm destaque as obras de BONNASSIE, P. La Catalogne du milieu du Xe à la fin du Xle siècle. Croissance et mutation d'une société. Toulouse, 1975-1976, 2v; BOIS, G. La mutation de l'an mil. Paris: Fayard, 1990; BOURNAZEL, E. e POLY, J-P. La mutation féodale. Paris: PUF, 1991. 
milites, mas não que estas torres escapavam ao poder condal. Dessa forma, a ascensão dos milites (guerreiros e cavaleiros) não indica o surgimento recente de uma nova classe responsável por novas violências. No ano mil os milites não formam uma classe, mas um a profissão dirigida pela aristocracia leiga e eclesiástica. Essa profissão também não é nova, mas está em mutação. Por fim, assim como a proliferação das torres, as exações de então não precisam ser atribuídas aos novos cavaleiros autônomos, nem a castelos independentes. A ascensão dos milites não dependeria assim, da "revolução feudal" e, portanto, da perda de controle do poder público pelos condes."

Um exemplo um pouco mais objetivo e de grande relevância é oferecido pela Paz de Deus, ${ }^{10}$ movimento conciliar que visava constranger a aristocracia guerreira à paz, e que ocupou por muito tempo lugar de excelência como prova da "mutação feudal". A Igreja pressionada pelo aumento desenfreado da violência geral, frente ao vazio de poderes públicos, se apropria de uma função exclusivamente real e passa a agir em favor do controle da aristocracia através de sanções espirituais, ameaças materiais e fundamentando ideologicamente a promoção social daqueles guerreiros alinhados com seus ideais pacificadores. O movimento de paz atestaria o aumento da violência e a perda de controle dos grandes sobre os guerreiros ascendentes por intermédio da privatização da força militar. ${ }^{11}$ Escrevendo contra este modelo, Karl Ferdinand Werner mostrou que ao procurar promover a paz, a Igreja não usurpava funções reais, mas lançava mão de uma prerrogativa de ordem pública que lhe fora conferida pelo próprio poder real. Desde pelo menos o século IX, a legislação carolíngia conferia aos bispos autoridade em questões relativas à ordem pública. Os bispos puderam dessa forma, exercendo uma função pública que the fora delegada, zelar pelo cumprimento de uma legislação pertinente aos bens eclesiásticos existente desde o período merovíngio. Werner também insiste em que, baseada nesta legislação, a Igreja não tinha pretensão ao

9 A crítica à generalização do modelo maconesiano desenvolvido por Duby, com particular destaque para Eric Bournazel e Jean-Pierre Poly, é feita de forma contundente por Jean Flori e por Dominique Barthélemy, cujas considerações nos orientaram na exposição da síntese acima apresentada. Ver: BOURNAZEL, E. e POLY, J-P. La mutation féodale (Xe - XII siècles); FLORI, J. La guerre sainte. La formation de l'idée de croisade dans l'Occident chrétien. Paris: Aubier, 2001, p.61-69; BARTHÉLEMY, D. La paix de Dieu dans son contexte (989-1041). Cahiers de civilisation médiévale, v.40, p.3-35, 1997; BARTHÉLEMY, D. L'an mil et la paix de Dieu. La France chrétienne et féodale, 980-1060. Paris: Fayard, 1999; BARTHÉLEMY, D. La mutation de l'an mil a-t-elle eu lieu? Servage et chevalerie dans la France des X et XI siècles, Paris: Librairie Arthème Fayard, 1997 e BARTHÉLEMY, D. A cavalaria.

10 A cronologia da Paz de Deus é discutível. Nem todos consideram o concílio de Charroux (989) sua primeira manifestação, contando assembléias de paz que datam de vinte anos antes (como Aurillac-Coler em 972). Para o encerramento do movimento por vezes se evoca a Trégua de Deus (c.1030), o início das cruzadas (1095) ou a "Paz do rei" (paz de Luiz VII em 1155). Adotamos a segunda opção, estabelecendo como limite cronológico desta pesquisa o momento em que o papado passa a conformar o movimento ao retomar, em Clermont, as disposições promulgadas pelos concílios de paz.

11 Novamente a grande referência é DUBY, G. Os leigos e a paz de Deus. In: A sociedade cavaleiresca. São Paulo: Martins Fontes, 1989, p.37-47. 
estabelecimento de uma paz geral, mas de defesa de seus bens ${ }^{12}$ e, se considerarmos a Trégua de Deus, podemos mesmo dizer, que de salvaguarda de suas prerrogativas sacras e litúrgicas. ${ }^{13}$

A igreja não pretendia o controle da violência, mas realizar com o apoio dos grandes uma paz em nome de Deus, colocando os bens eclesiásticos no plano puramente espiritual. Dentro do espírito reformista que primeiro se esboçara em Cluny, procura-se colocar os assuntos pertinentes à igreja exclusivamente nas mãos de Deus, ou seja, do clero. A Paz de Deus é uma etapa do progresso da independência da Igreja. A parceria com os grandes senhores evidencia que o assunto é reconhecido como pertinente à sua autoridade pública e que promover a paz é um gesto de governo.

As Histórias de Raul Glaber são um dos textos que tradicionalmente compõem o dossiê favorável tanto à "mutação feudal" quanto da interpretação "mutacionista" da "Paz de Deus". No entanto, face à idéia de desaparecimento dos poderes públicos atestada pela generalização da violência, o que podemos observar na obra do monge burguinhão é que em nenhum momento a realeza e os grandes senhores saem de seu horizonte de análise. Sua história se orienta por eles e lhes atribui papel importante. Nesta narrativa, cheia de guerras e de revezes militares, nada faz pressupor que a autoridade do rei da França ou do imperador, estejam em causa ou estejam deslocadas das atribuições de governo que lhe são reconhecidas. O prólogo das Histórias é claro ao atribuir a estas duas figuras um papel de destaque na narrativa que se confirma ao longo de seus cinco livros:

Farei primeiramente ver (pois podemos afirmar com certeza, ainda que o cômputo dos anos decorridos desde a criação do mundo feito pelas histórias dos hebreus difira daquele da tradução dos Setenta) que o segundo ano que seguiu o milênio do Verbo encarnado foi também o primeiro ano do reino de Henrique, rei dos Saxões, e que o milésimo ano de nosso Senhor foi também o décimo terceiro do reino de Roberto, rei dos francos. Deste lado do mar, todos os dois eram considerados como os mais cristãos e os maiores reis; o primeiro, Henrique chegou em seguida ao Império romano. Também colocamos a lembrança dele na origem de nossa cronologia. ${ }^{14}$

12 WERNER, Karl Ferdinand. Le rôle des évêques dans les mouvements de paix au Xe et Xle. siècles. In: Mediaevalia christiana. Paris: De Boeck, s/d, p.155-195.

13 A Trégua de Deus geralmente é interpretada como a tentativa da Igreja estabelecer o controle do tempo lícito para a guerra, na tentativa de reduzi-la ao mínimo possível. Pensamos, no entanto, que a Trégua de Deus, enquanto ainda proposta circunscrita ao ideal eclesiástico se ocupa menos da guerra do que da defesa frente aos guerreiros da especificidade do tempo litúrgico e da autoridade reservada à Igreja sobre o mesmo. Isso ganha sentido se pensarmos que o contexto reformista monástico em que se dá o movimento de paz, é marcado pela tentativa da Igreja de estabelecer a distinção física e simbólica dos domínios consagrados, construindo dessa forma a libertas ecclesiae. O respeito à Trégua pelos guerreiros assinalaria seu reconhecimento da autoridade espiritual e a natureza igualmente espiritual de seus domínios objetivos (o tempo litúrgico e o espaço de seus senhorios, por exemplo).

14 GLABER, Raul. Histórias, I, 1 
A afirmação de Glaber não se limita a fazer dos reinados de Roberto e Henrique referenciais cronológicos, como pode parecer à primeira vista. Observando-se o conjunto da obra é possível notar que estas duas realezas formam o núcleo para o qual as atenções da narrativa histórica de Raul retorna periodicamente. É o acompanhamento de ambas que confere sentido geral aos dados narrados, que de outra forma, ficariam dispersos e teriam sua lógica histórica comprometida. O texto exibe por intermédio das duas realezas a existência de uma lógica histórica geral marcada pela alternância entre momentos de equilíbrio e de desequilíbrio. No entanto, fica evidente que esses desequilíbrios não afetam de forma decisiva o equilíbrio geral que sempre marca o desfecho das narrativas. Os dados que mostram as rebeliões, guerras e traições sofridas por estes reis são sempre finalizados pela recomposição da ordem que na verdade sempre é apenas fracamente abalada. Para Glaber mais do que as pessoas de Roberto e Henrique, importa deixar claro o caráter firme e constante da realeza. Ilustra isso o fato de que a descrição do esplendor e subseqüente desaparecimento da dinastia carolíngia, descrito no prólogo não carrega nenhum tom de lamento, não representa nenhuma catástrofe tendo em vista que, do ponto de vista de Glaber, a realeza se mantém e o desempenho esperado de suas funções não foi alterado. O milésimo ano da encarnação do Verbo não anuncia decadência, mas qualifica a excelência do momento em que se dão os reinados de Roberto e Henrique, "Deste lado do mar (...) os mais cristãos e os maiores reis".

A obra de Raul se encerra num elogio, cheio de esperanças em torno da eleição do novo papa, um reformista ("homem de grande piedade e vida santa"). ${ }^{15}$ Sua saudação não indica que visse na eleição uma nova era política. Como reformista bem estabelecido no círculo de Guilherme de Volpiano, Raul professa uma concepção particular da reforma monástica que não se identifica perfeitamente à visão que dela têm os cluniacenses. A eleição do novo pontífice, para Raul aponta para uma nova ordem desejada por alguns, em que a Igreja se vê poderosamente estabelecida dentro dos limites de poder espiritual, inacessível à interferência leiga. Portanto, nada lembra uma obra orientada pela insegurança produzida pela violência endêmica e por imperativos e expectativas escatológicas ou milenaristas ou o avanço de uma sociedade idealizada sob a hegemonia política da Igreja romana ou monástica.

O comentário da violência e da apresentação do exercício do poder na obra de Glaber pede de início uma reflexão a respeito da natureza da documentação. Apresentamos acima algumas dúvidas possíveis a respeito da objetividade das informações contidas nos documentos tendo em vista,

15 Como a data exata de finalização das Histórias não é conhecida (1046? ou 1047?), não há consenso em torno de quem seria este papa. Provavelmente trata-se de Gregório VI. GLABER, Raul. Histórias, v.V, p.26. 
sobretudo, dois elementos: o aspecto conservador da composição textual, ou seja, o recurso desejável e mesmo necessário no período, a fórmulas de composição de gêneros narrativos diversos, a temas e a modelos explicativos emprestados às autoridades do passado; depois, o comprometimento social limitado das obras medievais que nos levam quase sempre ao contato com textos comprometidos com grupos dominantes - os únicos capazes não apenas de promover a elaboração do material escrito, mas, sobretudo, de garantir sua conservação. Uma das possibilidades que merece investigação é em que medida o próprio gênero narrativo das "histórias" pode nos ajudar a perceber se existe um compromisso cultural em destacar as narrativas de violência guerreira e se existe uma forma estereotipada de apresentação da guerra. O gênero "história" surge fortemente comprometido com a guerra como tema de primeira grandeza tanto em Heródoto (que faz dela parte essencial dos "feitos maravilhosos e admiráveis" que cabe à história evitar que o tempo apague ${ }^{16}$ quanto em Tucídides, onde ela é o processo que demanda prioritariamente a intervenção da principal função da história, a inteligibilidade. ${ }^{17}$ Evidentemente que as distâncias entre estas e as narrativas históricas medievais existem e são importantes. Gostaríamos apenas de lembrar que o destaque concedido à violência guerreira não é exclusivo das narrativas medievais. Nas narrativas estabelecidas por Heródoto e Tucídides, que se tornaram exemplares do gênero que ajudaram a criar, a objetividade dos conflitos narrados é menos importante do que a capacidade que demonstraram de definir grupos constituídos a partir da conjunção de critérios, de afinidade, proximidade e aliança. ${ }^{18}$

16 I, 1 "Os resultados das investigações de Heródoto de Halicanassos são apresentadas aqui, para que a mamória dos acontecimentos não se apague entre os homens com o passar do tempo, e para que os feitos maravilhosos e admiráveis dos helenos e dos bárbaros não deixem de ser lembrados, inclusive as razões pelas quais eles guerrearam". HERÓDOTO. História. Tradução de Mário da Gama Kury. Brasília: Editora da Universidade de Brasília, 1985.

17 Tucídides atrasa um pouco mais a apresentação de sua proposta para o final do prólogo (capítulos 20-23) do Livro I. "A explicação mais verídica, apesar de menos frequentemente alegada é, em minha opinião, que os atenienses estavam tornado-se poderosos, e isto inquietava os lacedemônios, compelindo-os a recorrerem à guerra." (capítulo 23). Em seguida Tucídides passa a descrever as "razões publicamente alegadas pelos dois lados" para o início do conflito, das quais ele diverge por meio do argumento analítico mencionado há pouco. Essas "razões publicamente alegadas" arrolam a descriçào por um lado dos discursos que moveram os espíritos à guerra e por outro a descrição das batalhas, suas razões imediatas bem como, condições materiais. Todo esse grupo de elementos que tem validade explicativa corrente, têm sua capacidade explicativa posta em xeque por Tucídides. Em seu lugar ele propõem uma formula que confere inteligibilidade comum a todos os fatos, entendendo que esta inteligibilidade é o objetivo final da história. Cabe à ela dar clareza ao que parece de início, escapar a princípios gerais de inteligibilidade. Daí poder afirmar depois de sua cuidadosa crítica dos testemunhos que "Pode acontecer que a ausência do fabuloso em minha narrativa pareça menos agradável ao ouvido, mas quem quer que deseje ter uma idéia clara tanto dos eventos ocorridos quanto daqueles que algum dia voltarão a ocorrer em circunstâncias idênticas ou semelhantes em consequência de seu conteúdo humano, julgará a minha história útil e isso me bastará". TUCÍDIDES. História da guerra do Peloponeso. Tradução feita por Mário da Gama Kury. Brasília :Editora da Universidade de Brasília, 1986.

18 Em Heródoto vemos a acentuação da diferença entre gregos e bárbaros por meio das afinidades lingüísticas (que ele admite nem sempre consistentes) e de alianças, se estabelecer de maneira decisiva ao longo das guerras pérsicas. Em Tucídides tanto as grandes guerras mobilizam formas de associação que podem resultar em duradouras após seu desfecho. 
Segundo Arnaldo Momigliano, o "sub-gênero" história eclesiástica, inaugurado por Eusébio de Cesaréia no século IV, constitui a principal contribuição do cristianismo para a historiografia de seu tempo. ${ }^{19}$ De fato, a obra de Eusébio foi influente na historiografia cristã subseqüente, sem limitar-se às histórias propriamente eclesiásticas. O texto da História eclesiástica, diversas vezes reescrito por Eusébio, começa com uma história da Igreja - no sentido de história da comunidade de crentes sob a direção de seus bispos mais destacados. No entanto, podemos dizer que sua história termina menos eclesiástica do que começou na medida em que se abre para os horizontes do Império, passando das conquistas dos bispos e dos mártires cristãos, para a vitória de Constantino contra Licínio, transformada em vitória cristã. A obra termina apontando para uma dimensão histórica mais vasta que acolhe o Império e a autoridade pública reconhecida. No entanto, é preciso dizer também que este final é coerente com um elemento capital da lógica histórica apresentada no texto, desde suas primeiras linhas. A história segundo a visão eusebiana é marcada pela noção de conflito. De seu ponto de vista, estes conflitos têm duas naturezas: podem ser internos ou externos. Sua resolução se dá tanto através dos instrumentos da fé quanto da política, considerando-se aqui a interferência tanto da autoridade moral do imperador quanto aquela das armas materiais sob seu comando.

Os célebres parágrafos do prólogo da obra de Eusébio apresentam de forma sucinta o plano fundamental da obra:

\begin{abstract}
A sucessão dos santos Apóstolos, assim como o intervalo de tempo entre o Salvador e nós; a enumeração de tantos e tão importantes eventos no curso da história eclesiástica; quantos nela mencionados presidiram e governaram com destaque as dioceses mais ilustres; em cada geração, quantos foram deputados para ministrar a palavra divina oralmente ou por escrito; quantos e quando os que, arrastados a erros extremos pela atração das novidades, anunciaram e introduziram uma falsa ciência (I Tim. 6,20), e semelhantes a lobos rapaces (At. $20,29)$ cruelmente dizimaram o rebanho de Cristo.

Além disso, as tribulações sobrevindas a toda a nação judaica, logo após as insídias contra nosso Salvador: quantos, quais, em que tempo os ataques dos pagãos contra a palavra divina; os grandes varões que, em várias épocas, por ela suportaram suplícios e combateram até o derramamento do sangue; sobretudo, entre nós, os testemunhos prestados e a benevolência misericordiosa do salvador para conosco - tudo isso julguei conveniente transmitir por escrito. Não quero outro exórdio a não ser a realização da "economia" de nosso Salvador e Senhor Jesus, o Cristo de Deus. ${ }^{20}$
\end{abstract}

19 MOMIGLIANO, Arnaldo. As origens da historiografia eclesiástica. In: As raízes clássicas da historiografia moderna Bauru: Edusc, 2004, p.187-212

20 DE CESARÉIA, Eusébio. História eclesiástica. I, 1-2 
O texto de Eusébio desenha uma concepção da história da comunidade cristã - que já dissemos, tende a ampliar até os limites do Império - marcada por um duplo conflito: um representado pelas dissensões internas provocadas pelas heresias, a "falsa ciência" de "lobos rapaces" e outro externo, configurado pelas lutas contra infiéis e pagãos. A entrada em cena não apenas do Império, mas do imperador, transformado em campeão da causa divina, ${ }^{21}$ e, portanto, cristã, em contexto de liberação do culto eleva esses conflitos morais e espirituais ao nível da luta militar. Esse duplo conflito tem uma posteridade insuspeita na concepção cristã de história. Isso acontece por que a eficácia do modelo explicativo cristão se fundamenta na idéia de uma memória histórica comum. Não apenas o cristianismo advoga que todos têm origem num mesmo homem criado por Deus, mas que todos têm a mesma memória histórica de seu passado, mesmo que "esquecida" devido ao pecado. ${ }^{22}$ A cristianização implica, portanto, numa transformação radical da memória do passado, trocada por uma memória histórica bastante precisa quanto ao passado, ao presente e ao futuro do homem. Essa memória histórica depende particularmente de sua capacidade de sua difusão permanente já que nela está contida a explicação da sociedade e garantida uma memória que deverá ocupar o lugar daquela apagada pela conversão. Tais são as particularidades fundamentais da concepção cristã de história à qual talvez esteja relacionada à própria longevidade da valorização social da explicação história no ocidente.

Antes de voltarmos a Raul Glaber, podemos pressentir um pouco meIhor como o modelo do duplo conflito marcou a história cristã, articulando ação espiritual e guerreira, se observarmos o prólogo de uma outra obra historiográfica bastante influente, Os dez livros de história escrita pelo bispo Gregório de Tours. Os propósitos do autor são esclarecidos no prólogo da obra em termos que não nos são estranhos:

Antes de descrever as lutas dos reis com as nações adversas, aquelas dos mártires com os pagãos, aquelas das igrejas com os heréticos, desejo confessar minha fé para que aquele que me leia não duvide de que sou católico. Desejei também para aqueles aos quais desespera a aproximação do fim do mundo, indicar claramente o número de anos que se passaram depois do começo do mundo recolhendo nas crônicas e nas histórias um resumo dos fatos passados. Mas primeiramente peço aos leitores que me desculpem se nas letras e nas sílabas, acontecer de que eu transgrida as regras da arte da gramática que não possuo plenamente. Meu único cuidado é reter sem nenhuma alteração nem

21 A vitória de Constantino contra Licínio (de cujas forças se diz serem compostas pelos "inimigos de Deus") é descrita como facilitada por Deus a seu aliado, "muito amado de Deus". Essa vitória elimina "do mundo o ódio a Deus". Com ela, o Império reunificado submeteu-se a um "pacífico governo" (X, 9, 4, 6 e 9). Utilizamos a segunda edição da tradução da História eclesiástica feita diretamento do grego pelas Monjas beneditinas do mosteiro de Maria Mão de Deus para a editora Paulus, aparecida em 2008.

22 PINHEIRO, Rossana Alves Baptista. Edificação da memória nos escritos de Martinho de Braga. Caminhos da expansão do cristianismo na Gallaecia do século VI. Franca: Unesp, 2004 (História, Dissertação de Mestrado). 
hesitação de coração o que se manda crer na Igreja, pois sei que aquele que se tornou culpável de pecados pode obter o perdão de Deus por sua fé. ${ }^{23}$

A história de Gregório tem como objetivo os mesmos conflitos presentes na obra de Eusébio, as lutas externas contra os pagãos e as lutas internas contra as heresias, em ambas, os reis atuam de maneira decisiva. Esse dado ganha mais importância diante do fato de que a obra de Eusébio, dentre as obras de história que nos chegaram da Idade Média, tem sua interpretação particularmente dependente da valorização da violência guerreira aí descrita. Essas análises pouco atentaram para a possibilidade de que a valorização desses conflitos - não negamos que eles tenham ocorrido - possa ser resultante simplesmente da utilização de um sistema histórico explicativo dado por uma tradição cujo exemplo primeiro é dado pela obra de Eusébio. Décadas depois de Eusébio ter encerrado sua história eclesiástica, Agostinho, discutindo o poder regenerador do homem decaído pelo batismo, acaba por fazer uma defesa quase definitiva da necessidade de coerção não apenas sobre pagãos, mas também sobre cristãos batizados. Àqueles que argumentavam que o batismo não apenas retirava as máculas dos pecados passados, mas impossibilitava de pecar, tornando a coerção desnecessária, Agostinho responde, exemplificando com os movimentos incontroláveis da libido, que o homem, mesmo que cristão, estava constrangido por sua condição decaída à necessidade de coerção. ${ }^{24}$ A violência ganhava assim uma importância ainda maior na concepção cristã de sociedade histórica. Numa sociedade mais clara e seguramente cristã que a de Eusébio, marcada pela instabilidade militar e pelas dissensões entre cristãos não apenas por questões doutrinárias, mas também disciplinares, sobretudo no tocante ao estabelecimento da hegemonia bispal sobre as comunidades cristãs, a posição de Agostinho estava fadada a estabelecer-se. A idéia da coerção necessária, dessa forma, veio somar-se, fortalecer e complementar aquela de uma sociedade cristã envolvida em conflitos permanentes de ordem interna e externa.

Nesse modelo de sociedade histórica, o poder público não tem as pretensões administrativas das formas de governo modernas, mas tem funções no topo das quais se encontram os discursos e as ações de paz. Assim, em Raul Glaber, se a violência é apontada, ela aparece sem que o rei e o imperador deixem de ser observados como autoridades referenciais de primeira importância. Mais do que isso, à luz do que dissemos agora, as violências dão ocasião para o exercício de uma de suas funções fundamentais, integrando os signos de legitimidade do poder. Entre os cristãos,

23 DE TOURS, Gregório. Os dez livros de história, I, 1.

24 SENELLART, Michel. As artes de governar. Do regimen medieval ao conceito de governo. São Paulo: Editora 34, 2006, p.72-89. 
a aproximação histórica entre o modelo constantiniano de poder e a idéia agostiniana da coerção necessária, temos as autoridades públicas legitimadas por meio de ações de paz.

Em Guerreiros e camponeses, livro publicado pela primeira vez em 1947, portanto produzido no mesmo contexto de reflexão que deu origem ao artigo anteriormente mencionado, Georges Duby apresenta uma Alta Idade Média em que as ações guerreiras ocupam o lugar de primeiro plano. Nesta obra escrita ainda sob influência teórica marxista, ele afirma:

Nesse padrão de desenvolvimento, é igualmente necessário dar lugar aos fatores políticos, cuja intervenção levou o movimento de crescimento a dividir-se em duas grandes etapas. Por detrás da primeira que continuou até depois do ano 1000, as forças impulsionadoras mais óbvias eram de ordem militar, de agressão e conquista e mantiveram a vitalidade de importantes instituições econômicas, tais como a escravatura e as pilhagens periódicas. Esta fase do crescimento era, de início, fundamentalmente a de uma economia de guerra. ${ }^{25}$

Baseado nesta perspectiva, em 1980, Alain Guerreau em "Para uma teoria do feudalismo", texto com que encerra seu O feudalismo. Um horizonte teórico, ${ }^{26}$ confere tal destaque à guerra como fator histórico explicativo que o autor é levado a trabalhar com duas noções a fim de tratar o problema do "feudalismo": "feudalismo" e "lógica feudal". O primeiro termo se aplica mais precisamente ao momento em que o "feudo" passa a integrar de forma decisiva as alianças da aristocracia, dizendo respeito, portanto, aos séculos XI-XIII. O segundo termo, "lógica feudal", se refere a elementos que atravessam a Idade Média e que, do ponto de vista desse marxista crítico, duraria do século V ao XVIII. A lógica feudal seria dada pelas guerras privadas às quais caberia a distribuição de poder que - sem que o autor tenha utilizado este termo - podemos chamar de privatizado. Se também não podemos afirmar que o autor pensa em anarquia, é certo que sua insistência no desaparecimento dos instrumentos públicos de justiça, aponta para uma sociedade distante de formas de poder público e de governo. O autor desloca a razão da violência guerreira para a circulação que ela efetua dos senhorios fonte real mantendo a guerra como fator explicativo geral de primeiro nível.

Como procuramos argumentar anteriormente, a valorização da violência guerreira como fator explicativo global pelos medievalistas alimenta a reprodução da noção de que não existem formas de poder público e de governo atuantes no período. Dominique Barthélemy tem, por sua vez, argumentado veementemente em sua obra que devemos começar por

25 DUBY, Georges. Guerreiros e camponeses. Os primórdios do crescimento econômico europeu (séculos VII-XII). Lisboa: Estampa, 1978, p.86.

26 GUERREAU, Alain. O feudalismo. Um horizonte teórico. Lisboa: Ed. 70, s/d. 
colocar em xeque a própria noção de aristocracia guerreira, afirmando por exemplo, que os paramentos e cerimônias ligados às armas e mesmo à própria guerra fazem parte mais da exibição de atributos de poder do que do grupo de testemunhos certos da freqüência e intensidade da violência guerreira. Para este autor, as declarações inamistosas e as provocações nem sempre dão origem a conflitos com desfecho armado longo e cruento. Normalmente tais declarações, e até mesmo os cercos, são oportunidades para protelar o combate e dar oportunidade à solução negociada. ${ }^{27}$

Dois exemplos tirados da Alta Idade Média nos ajudarão nesta reflexão geral. Em primeiro lugar um trecho da Vida de Carlos, escrita pelo beneditino Eginardo, cortesão de Carlos Magno e depois conselheiro de seu filho, Luís, o Pio, por volta de 825-826:

A família dos merovíngios, na qual os francos tinham o costume de escolher seus reis, é reputada de haver reinado até Childerico que, por ordem do pontífice romano Estevão, foi deposto, teve os cabelos cortados e foi encerrado em um monastério. Mas parece, com efeito que ela [a família dos merovíngios] que não terminou senão com ele [Childerico], já havia, desde muito tempo, perdido todo vigor e somente se distinguia pelo insignificante título de "rei". A riqueza e o poder público estavam nas mãos dos chefes de sua Casa, que se chamavam prefeitos do palácio [major domus] aos quais pertencia o poder supremo. O rei não tinha, além de seu título, senão a satisfação de sentar-se em seu trono com sua longa cabeleira e barba pendentes e ali fazer figura de soberano, conceder audiência aos embaixadores dos diversos países e encarregá-los, quando retornavam, de transmitir em seu nome as decisões que lhes haviam sido sugeridas ou ditadas. Salvo o título real, tornado inútil, e os precários meios de existência que Ihes concedia, segundo sua própria vontade, o prefeito do palácio, ele possuía para si um único domínio de fraquíssimo rendimento, com uma casa e alguns poucos servidores à sua disposição para the fornecer o necessário. Quando tinha de deslocar-se, montava em um carro atrelado a bois, que um boiadeiro conduzia de maneira rústica: é com essa equipagem que ele tinha o hábito de ir ao palácio, de se conduzir à assembléia pública de seu povo, reunida anualmente para tratar dos negócios do reino, e em seguida voltar à sua residência. A administração e todas as decisões e medidas, no interior ou exterior, eram da exclusiva competência do prefeito do palácio. Essa função, à época em que Childerico foi deposto, era ocupada por Pepino, pai do rei Carlos, em virtude de um direito já quase hereditário. Com efeito, ela tinha sido brilhantemente exercida antes dele por outro Carlos de quem era filho e que se salientou ao abater tiranos cujo poder tentava se implantar por toda a França, e forçou os sarracenos em duas grandes vitórias - uma na Aquitânia, em Poities, a outra perto de Narbona - a renunciar a ocupação da Gália e recuar para a Espanha; esse último [Carlos Martel] a havia recebido do seu próprio pai, igualmente chamado Pepino; porque o povo tinha o costume de não a confiar senão àqueles que se tinham sobressaído pelo brilho de seu nascimento e importância

27 Uma análise bem detalhada a respeito que tem além do mais a virtude de refletir sobre a violência guerreira durante quase todo o período medieval pode ser encontrada em BARTHÉLEMY, Dominique A cavalaria. 
de suas riquezas. Pepino foi elevado, pela autoridade do pontífice romano, de prefeito do palácio à dignidade real". ${ }^{28}$

Este trecho célebre da Vita Karoli, pretende de forma evidente defender critérios que afirmam a legitimidade da sucessão carolíngia. O que nos interessa aqui é que o texto em que os reis merovíngios ganham o epíteto infamante de "indolentes" não aponta para o desaparecimento das instituições públicas sob os últimos merovíngios como se quis por vezes afirmar, mas ao contrário, ele afirma que o rei perde sua legitimidade porque não toma para si a gestão pública que passa a ser exercida pelos prefeitos do palácio. $\mathrm{Na}$ condução dos assuntos de governo, caracterizados no texto pela presidência de assembléias, pela representação frente a embaixadas externas, pela capacidade de tomar decisões e, por fim, pelo decoro em sua apresentação como representante do poder público, causa escândalo a forma como o rei procede - sem vontade decisória e sem capacidade de negociação interna, ou seja, sem riquezas - e se deixa apresentar para exercer suas funções públicas como ao se fazer levar às assembléias sobre um carro de bois, conduzido portanto sem nenhuma solenidade. A capacidade guerreira e o exercício efetivo do poder público são dois dentre uma série de argumentos (contra os merovíngios e em favor dos "carolíngios") nos quais Eginardo procura fundamentar a legitimidade do poder carolíngio. O mais importante dos fatores contrários aos merovíngios é que o rei não estava à altura nem interessado no exercício da realeza, que a despeito dele continuava existindo e exigindo ações de governo. Vimos essa mesma concepção do poder atuante também em Glaber, face ao desaparecimento dos carolíngios.

Os critérios de legitimidade apontados por Eginardo começam no berço, na qualidade das famílias em questão. O trecho citado acima evolui do início ao fim para mostrar a corrupção de uma família e a superioridade de outra. A excelência que garante o exercício do poder público se fundamenta primeiramente, segundo o próprio Eginardo, na família, (o "brilho do nascimento") e nas riquezas. Nisso, os ancestrais dos carolíngios foram incomparáveis aos últimos merovíngios. Na exemplificação oferecida por Eginardo dos gestos de governo dos prefeitos do palácio contam-se "a administração e todas as decisões e medidas no interior e no exterior (...) em virtude de um direito já quase hereditário" e o combate contra os tiranos e os sarracenos. A violência aparece no texto qualificada de três formas: realizada sob direção real; como atributo do poder público e parte das funções de governo, e como meio de assegurar a legitimidade real e a proteção da fé, no caso, contra o infiel. A guerra tem aqui um lugar importante na definição do que é reinar. A historiografia feitas no período medieval reserva um espaço de 
maior destaque para os registros de violência pois eles fazem parte da concepção cristã de história.

Entre 589 e 591, cerca de duzentos anos antes da obra de Eginardo aparecer, João de Biclaro, abade de Gerona, sob o domínio visigótico, escreve uma crônica referente aos anos 565-589 que culmina com a conversão de Recaredo ao cristianismo ortodoxo. A estrutura fragmentária da Crônica é acentuada pelo aparente caos da sucessão de conflitos narrados. Uma certa ordem aparece na insistência do autor em manter uma espécie de narrativa "comparada" entre os eventos relativos ao Império e ao reino visigótico. A obra se inicia chamando a atenção para a importância e a extensão dessa comparação: a afirmação das decisões tomadas pelo concílio de Calcedônia por Justino abre a crônica que termina com o concílio de Toledo, que, à maneira dos imperadores Constantino e Marciano - lembra o documento - fora convocado por Recaredo:

1. Na décima quinta indicção, como se disse, depois da morte de Justiniano, foi feito imperador dos romanos, seu neto, Justino, o Jovem.

2. No ano 53 dos romanos [567?] reinou Justino, o Jovem pelo espaço de onze anos. Este Justino, no primeiro ano de seu reinado, anulou o que fora feito contra o sínodo de Calcedônia e introduziu em toda a Igreja católica, para que fosse cantado pelo povo antes da oração dominical, o símbolo dos 150 padres reunidos em Constantinopla e louvavelmente acolhido pelo sínodo de Calcedônia.

3. Os povos armênios e iberos, os quais receberam a fé graças à pregação dos apóstolos de Cristo, impulsionados por Cosroes, imperador dos persas, ao culto dos ídolos, rechaçaram esta ordem tão ímpia e se entregaram com seus territórios nas mãos dos romanos; isto rompeu os pactos de aliança entre os romanos e os persas.

Segundo ano [568?]

1. Na cidade real os patrícios Etéreo e Adeo, que, com a ajuda de médicos queriam provocar a morte de Justino com venenos mas do que com o ferro, foram descobertos e obrigados a sofrer a pena capital; o primeiro foi devorado pelas feras e o segundo pereceu queimado pelas chamas.

2. Justino, filho do patrícios Germano e primo do imperador Justino, recebeu a morte em Alexandria pela conspiração de Sofia Augusta.

3. Nestes tempos, Atanagildo, rei dos godos na Espanha, chegou ao fim de sua vida e em seu lugar reina Liuva.

Terceiro ano [569?]

1. Os garamantes desejam e pedem, por intermédio de embaixadores de paz, unirem-se ao império e receber a fé cristã. Recebem ambas as coisas.

2. Teodoro, prefeito da África perece nas mãos dos mouros.

3. Nestes tempos, o povo macurritano acolhe a fé de cristo.

4. No ano terceiro deste império, Leovigildo, irmão do rei Liuva, se estabelece a despeito dele no reinado da Espanha Citerior, toma a Gosvinta, viúva de Atanagildo como esposa e restabelece de forma admirável, os antigos limites do reino dos godos, que se haviam reduzido por diversas rebeliões. ${ }^{29}$

29 DE BICLARO, João. Chronique. In: Analecta sacra tarraconensia. Edição e tradução de P. Alvares Rubiano. t.16, 1943. 
A forma, para nós, confusa desses primeiros parágrafos se repete nos seguintes. Poderíamos a partir disso, explicá-los pela falta de plano autoral e como um registro desordenado de desordens. Muitos viram na evocação do Império pela crônica uma tentativa meramente discursiva de imitação. Esta provaria a decadência da capacidade política com a instalação dos bárbaros, ou seja, o ocaso do poder público e assim a necessidade de evocar a comparação com as estruturas de poder romanas. No entanto, o que temos dos dois lados não é apenas a comparação entre duas realezas que convocam concílios, no detalhamento das ações confrontadas temos - se insistirmos em pensar em termos de rebaixamento da capacidade governativa - duas "barbáries", ou melhor, a "barbárie" romana apresentada como modelo de procedimento real e de qualificação histórica do reino visigótico. As crises dinásticas, as rebeliões internas ou as agressões externas se verificam de um lado e de outro e as atrocidades maiores - geralmente cortesãs (complôs e envenenamentos seguidos de punições cruéis) - se dão de um lado e de outro e não apenas entre os bárbaros. A ordem sobre a qual continua estabelecida, de um lado o império e de outro a realeza visigótica, tem uma mesma natureza. Ela é conflituosa, mas não exclui nem o controle superior desses poderes, nem ações de governo. A idéia de que as ações de governo teriam realidade meramente discursiva também não parece se sustentar diante do detalhamento dessas ações. Resumidamente, podemos ver a realeza tanto romana quanto visigótica, desempenhando segundo as circunstâncias, funções públicas do poder real que duzentos anos depois ainda caracterizam o poder eficaz entre os ancestrais dos carolíngios. Entre os visigodos, o rei defende a ortodoxia por meio de concílios, constrói igrejas e mosteiros, reúne e comanda diretamente o exército, efetua acordos militares, contrata mercenários para garantir a defesa, combate rebeliões, defende o território e também assegura sua ampliação acolhendo povos, realiza alianças, mantém a paz e a justiça restituindo bens, estendendo o domínio da lei; administra nomeando auxiliares, recebendo embaixadas, recebendo tributos, mantendo um tesouro público, concedendo privilégios ao povo das cidades e subúrbios, fundando cidades, realizando obras de defesa e comunicação.

Michel Senellart, ao discutir o conceito de "governo" na Idade Média, vê no período o predomínio de uma legitimação apenas moral do poder ${ }^{30}$ Mas diante do que foi dito, podemos nos perguntar se efetivamente devemos considerar que o governo no Ocidente medieval, devido à sua responsabilidade com a salvação de seus súditos ${ }^{31}$ se dá à revelia de outras formas de atuação. As informações trazidas pelos documentos apresentados nos

30 SENELLART, Michel. As artes de governar.

31 Que, aliás, implica os reis de formas diversas, de época para época, como aponta CÂNDIDO DA SILVA, Marcelo. A realeza cristã durante a Idade Média. São Paulo: Alameda, 2008. 
permitem acreditar que a comparação com os romanos não é meramente discursiva, que do ponto de vista da época não estamos diante de duas decadências, mas de uma experiência comum que justifica a violência e o poder segundo uma mesma lógica histórica.

A violência guerreira é instrumento de governo e de justiça. As guerras são a parte importante da coerção necessária que cabe ao governo e não sinal de seu ocaso. Elas defendem e corrigem (os "agressores" externos, os rebeldes internos, os infiéis, os pagãos e os hereges). A narrativa das guerras mostra sua ação organizadora permanente e torna evidente méritos daqueles que são eficazes em sua justa condução. Um dos conflitos destacados por Raul Glaber em suas Histórias é aquele travado contra os normandos. Ora, a despeito de todos os infortúnios que advieram das incursões normandas para os cristãos, Raul é o primeiro cronista a apontar já claramente que a paz com eles já era definitiva. Ele o faz não apenas tocado por sua sensibilidade superior, mas orientado pela previsibilidade de uma história que dá à violência bélica, conduzida de forma justa pelos poderes legítimos, papel ordenador e construtivo no campo da vida pública.

Por fim, gostaríamos de destacar que não pretendemos negar diferenças nos níveis de centralização do poder ao longo da Idade Média, nem que havia violência. Pretendemos questionar a validade teórica da análise do período que toma por base a associação entre descentralização política e desgoverno, privatização, ausência de poder público, tratando de um de seus fundamentos: o problema da violência. Quanto ao governo, pretendemos sugerir que o fato de não verificarmos padrões de centralização parecidos com os nossos não indica necessariamente que não haja instâncias públicas de poder reconhecido e atuante dentro de critérios particulares de ação.

Em 1155, Luis VII, um dos pilares da valorizada centralização monárquica francesa, declara paz em termos similares aos que viemos observando em que ainda se destaca como recurso de autoridade, a evocação da defesa da paz da Igreja.

Eu, Luís, pela graça de Deus rei da França. Afim de reprimir a febre dos maus e de cessar a mão violenta dos saqueadores, à pedido do clero e com a concordância do baronato, decretamos a paz em todo o reino. Por esta razão, no ano do Verbo encarnado de 1155, em 4 dos idos de junho, reunimos um concílio em Soissons. Aí estiveram presentes os arcebispos de Reims e de Sens assim como seus sufragantes, todos, como os barões, os condes de Flandres, de Troyes e de Nevers, e outros muito numerosos, e o duque da Borgonha.

Por sua vontade, prescrevemos que a partir da próxima festa de Páscoa, e por dez anos, todas as igrejas do reino e o conjunto de suas possessões, todos os camponeses, o grande e o pequeno gado igualmente, e para o que diz respeito à segurança dos caminhos, todos os mercadores onde quer que se encontrem e todos os homens onde quer que estejam - enquanto estejam prontos a vir em justiça diante daqueles que devem Ihes render justiça - tenham absolutamente 
todos a paz e plena segurança. Dissemos em pleno concílio e diante de todos, pelo verbo real, que observaríamos esta paz sem quebrá-la e que, se eles se reunissem para violar a paz prescrita, faríamos justiça em seu meio segundo nosso poder.

Juraram por esta paz o duque da Borgonha, o conde de Flandres, o conde Henrique, o conde de Nevers, o conde de Soissons e o resto da baronagem presente. O clero igualmente, os arcebispos e os bispos, os abades, prometeram, diante das relíquias sagradas e à vista de todo o concílio, observar esta paz, por seu lado, com todas as suas forças; e para que justiça seja feita às violências, eles prometeram nos ajudar segundo seu poder e o proclamaram na estabilidade da palavra consagrada.

Para que a coisa seja ouvida mais largamente e para que não se perca dela a lembrança, confiei à memória das letras a estipulação da coisa feita e a guarda da paz e nós ordenamos que fossem fortalecidas com a autoridade de nosso selo. ${ }^{32}$

O documento mostra que os cuidados com a paz fazem parte das funções públicas. No caso, a deliberação dá duas vezes oportunidade ao rei - primeiro no concílio, depois por meio da divulgação da deliberação redigida - de exibir a qualidade e extensão das alianças do rei e da estabilidade por ele imposta. O clamor pela paz, portanto, mais do que denúncia do império de desordens, evidencia que fazer a paz é governar.

Por fim, se a ruptura no plano do exercício de um poder público entre Idade Média, Antiguidade e Idade Média e Modernidade pode ser questionada, ainda resta definir com minúcias as especificidades desse poder público, ou seja, as mudanças que se operam na passagem da tradição antiga e para a tradição moderna. Para fazê-lo é evidentemente fundamental o abandono do uso isolado do referencial dado pelos valores políticos modernos, bem como a crítica dos documentos medievais para que se possa também compreender, por meio dos critérios que esses historiadores utilizaram para escrever a história medieval, em que medida eles podem ser úteis à reformulação dos recursos que empregamos para a análise do período.

32 Decreto geral de paz de Luis VII da França (10/06/1155). Apud: Recueil des historiens des Gaules et de la France. Paris: Imprimerie Impériale, 1806, t.XIV, p.387-388. 